\title{
The Meat Quality and Sensory Characteristics of Turkish Native Sheep Genotypes
}

\begin{abstract}
Engin Yaralı, ${ }^{1, a *}$
${ }^{1}$ Çine Vocational School, Aydın Adnan Menderes University. 09500 Çine/Aydın, Turkey

*Corresponding author

\begin{tabular}{|c|c|}
\hline ARTICLE INFO & A B S T R A C T \\
\hline $\begin{array}{l}\text { Keywords: } \\
\text { Meat quality } \\
\text { Fatty acid } \\
\text { Sensorial properties } \\
\text { Sheep genotypes } \\
\text { Carcass characteristics }\end{array}$ & 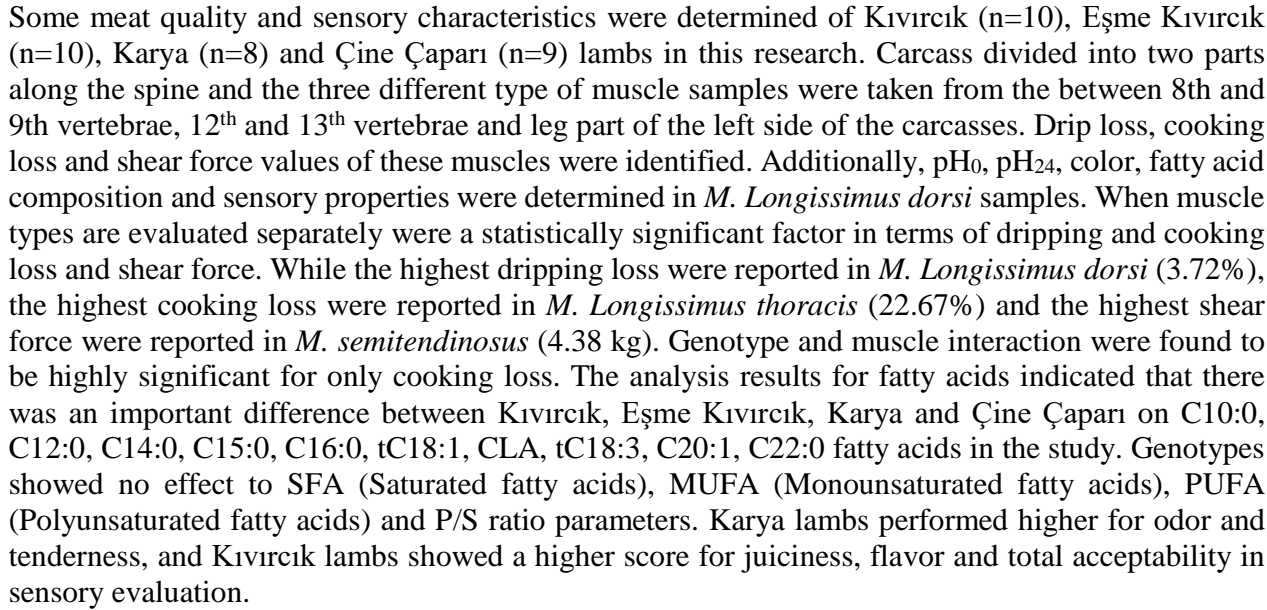 \\
\hline
\end{tabular}
\end{abstract}

Türk Tarım - Gıda Bilim ve Teknoloji Dergisi, 9(6): 961-967, 2021

\section{Türkiye Yerli Koyun Genotiplerinin Et Kalitesi ve Duyusal Özellikleri}

\begin{tabular}{|c|c|}
\hline M A K A LE B İ L G İ S İ & Ö Z \\
\hline $\begin{array}{l}\text { Anahtar Kelimeler: } \\
\text { Et kalitesi } \\
\text { Yağ asitleri } \\
\text { Duyusal özellikler } \\
\text { Koyun genotipleri } \\
\text { Karkas özellikleri }\end{array}$ & 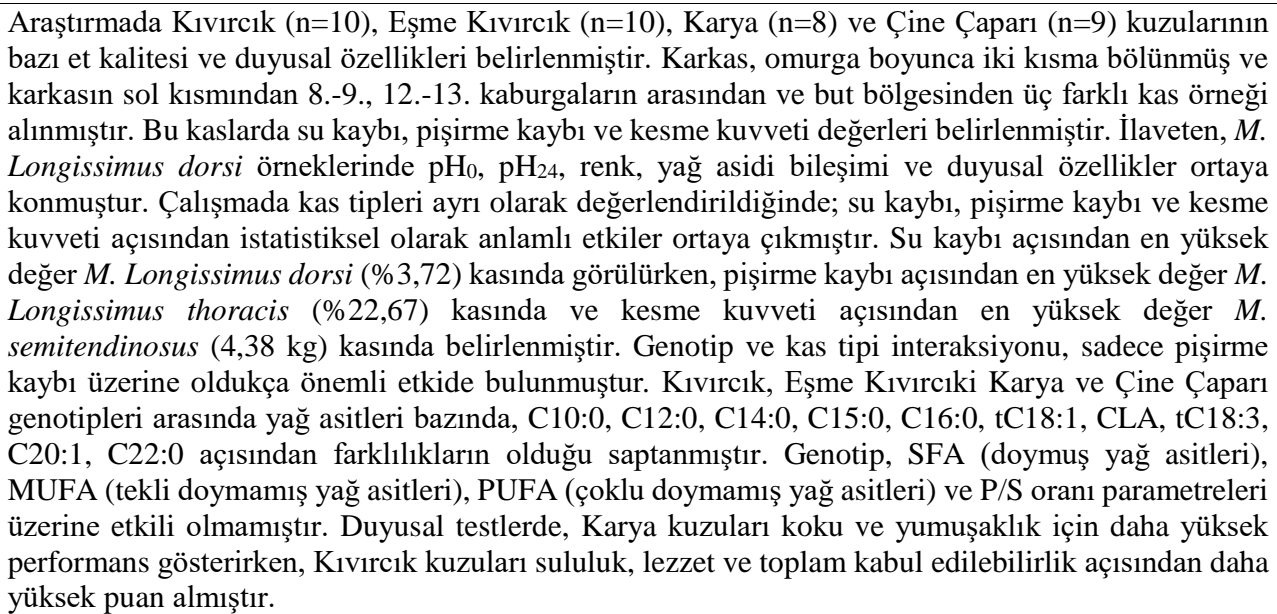 \\
\hline
\end{tabular}




\section{Introduction}

Meat production is the most important source of income in the sheep industry in Turkey (Ünal and Akçapınar, 1996). There are several factors that affect the quality and quantity of meat production. Mainly, these may be classified as genetic and environmental factors such as breed, sex, climate, slaughter hygiene and procedure (Sanudo et al., 1998; Priola et al., 2001). Meat structure, biochemical changes in muscle occured before and after slaughtering, technological and organoleptic properties of meat are influenced by these factors (Hopkins and Fogarty 1998; Gardener et al., 1999; Beriain et al., 2000).

In recent years, consumer's preference for meat with low fat content. Negative management and feeding conditions cause excessive fat in lamb, which this reduces consumer demand. Therefore, the implementation of efforts to improve the quality of meat, as well as to determine the current status of the local genotypes and breeds are also very important. Lamb meat quality is determined using some parameters such as carcass, meat and eating quality characteristics. Eating quality is evaluated with intramuscular adiposity associated with sensorial parameters such as softness and juiciness. For breeders, improving meat quality characteristics is difficult due to technological, financial and biological limitations. Lamb carcass is desirable to include a high proportion of polyunsaturated fatty acid, low fat, high parts of valuable carcass ratio, highquality tenderness, color, juiciness and sensory characteristics (Sanudo et al., 1998; Priola et al., 2001).

Kıvırcık, Eşme Kıvırcık, Karya and Çine Çaparı sheep genotypes are raised in Western Anatolia and Marmara part. From these genotypes, Kıvırcık and Eşme Kıvırcık sheep are known meat quality and production are raised in the Western part of Turkey. Kivircik sheep is at risk of extinction (Ceyhan et al., 2007). Karya sheep, which are known for their high fertility and growth characteristics. Cine Capari sheep which is a regional native fat-tailed sheep genotype of Aydin province has rather decreased due to backcrossing and is high lamb survival rate. The aim of this study was to determine some meat quality and sensory properties of Kıvırcık, Eşme Kıvırcık, Karya and Çine Çaparı lambs.

\section{Material and Method}

The procedure approved by the Aydin Adnan Menderes University Local Ethics Committee, which conform with EU Directive 86/609/EEC for animal experiments (124HEK/2009/53 Date: 02.09.2009).

\section{Animals and Diets}

Animal material for the study consisted of 37 Kivircık (KIV), Eşme Kıvırcık (EK), Karya (KR) and Çine Çaparı (CC) (Table 1) with an average age of five month that were grown in individual pens at the animal house facilities at Aydın Adnan Menderes University, Agriculture Faculty, Department of Animal Science. When the mean lamb age in the flock reached about 75 days, the lambs were weaned at same time. The fattening period continued for 70 days and each group of lambs were given ad-libitum concentrate feed $\left(20.4 \%\right.$ crude protein and $\left.2728.3 \mathrm{kcal} \mathrm{kg}^{-1} \mathrm{ME}\right)$ during this time. The good quality wheat straw (100 g) and fresh clean water were provided until slaughter.
Table 1. Sample Size and Sampling Location of Animal Material

\begin{tabular}{l|lc}
\hline \multicolumn{1}{c|}{ Genotype } & \multicolumn{1}{|c}{ Location } & N (head) \\
\hline KIV & Bursa & 10 \\
EK & Eşme-Uşak & 10 \\
KR & ADU-GSBP (Aydın)* & 8 \\
CC & Aydın & 9 \\
Total & & 37 \\
\hline
\end{tabular}

KIV $=$ Kıvırcık, EK= Eşme Kıvırcık, $\mathrm{KR}=$ Karya, $\mathrm{CC}=$ Çine Çaparı, *Adnan Menderes University Group Sheep Breeding Program Karya elite flock

\section{Slaughter Procedures and Carcass Characteristics}

Animals transported one day before slaughter to avoid transport stress and rested in paddock found in slaughterhouse at the end of the fattening period. Preslaughter live weight was recorded after the animals were fasted for $12 \mathrm{~h}$ with free access to water. After the slaughter, internal organs, skin and head were removed. After the hot carcass was weighed, it was maintained at $4^{\circ} \mathrm{C}$ for $24 \mathrm{~h}$ in cold storage and cold carcass weight was determined. M. Longissimus thoracis (MLT), $M$. Longissimus dorsi (MLD) and M. semitendinosus (MST) muscle samples were taken from the between $8^{\text {th }}$ and $9^{\text {th }}$ vertebrae, $12^{\text {th }}$ and $13^{\text {th }}$ vertebrae and leg part of the left side of the carcasses, respectively.

\section{Meat Quality Analysis}

The $\mathrm{pH}$ and fresh meat color $\left(L^{*}, a^{*}, b^{*}\right)$ were performed directly in the $M$. longissimus dorsi muscle between $12^{\text {th }}$ and $13^{\text {th }}$ vertebrae. Carcass $\mathrm{pH}$ was measured using a digital $\mathrm{pH}$ meter at 0 minutes after slaughter $\left(\mathrm{pH}_{0}\right)$ and 24 hours post slaughter $\left(\mathrm{pH}_{24}\right)$. Lightness $(L)$, redness $\left(a^{*}\right)$ and yellowness $\left(b^{*}\right)$ values were obtained using colorimeter (Minolta CR 400) for determining of color properties.

In this study, some meat properties in $M L D, M L T$ and MST muscle samples are examined for the meat quality characteristics. Cooking loss $(\%)$ and drip loss $(\%)$ were performed by the method described by Hofmann. et al. (2003). Drip loss was calculated as the percentage of weight loss from the starting weight (Honikel, 1998). To determine the water holding capacity, approximately $50 \mathrm{~g}$ portion of $M L D$ were cut and weighed. After, this muscle sample placed in plastic bags. The meat sample was hung in closed polyethylene package (left to the effect of gravity) and kept at $4{ }^{\circ} \mathrm{C}$ degrees for 48 hours. At the end of the dwell time, the piece of meat was weighed again and the result obtained was proportional to the initial weight. Shear force values were obtained using a Zwik/Roell texture analysis tester equipped with a V-shaped blade $\left(60^{\circ}\right.$ angle). Firstly, the muscle samples were cooked for $35 \mathrm{~min}$ at $75^{\circ} \mathrm{C}$ in a waterbath. After, samples were cooled to room temperature, they were blotted dry using paper towel. From each muscle type six $1 \mathrm{~cm}^{2}$ subsamples were cut parallel to muscle fiber and this samples tested using texture analyser.

\section{Fatty Acid Composition Analysis}

The composition of fatty acid in the muscle sampled from M. Longissimus dorsi was performed by gas chromatography (Tokuşoğlu, 2005). Fatty acids between C10:0-C24:0 and conjugated linoleic acid (CLA) have 
been determined in this research. Additionally, SFA (saturated fatty acids), MUFA (monounsaturated fatty acids), PUFA (polyunsaturated fatty acids) and P/S ratio values were calculated.

\section{Sensory Assessment}

The M. Longissimus dorsi muscle (100 g) sampled from all studied genotypes for sensory analyses were packaged under vacuum at $4{ }^{\circ} \mathrm{C} 24 \mathrm{~h}$ after slaughter. After this step, the samples were frozen and stored at $-18^{\circ} \mathrm{C}$ until panel evaluation. One day prior to panel test, frozen samples were thawed at $4^{\circ} \mathrm{C}$ for $24 \mathrm{~h}$. Samples were cooked in an electric oven at $180^{\circ} \mathrm{C}$ until the internal temperature reached $80^{\circ} \mathrm{C}$. Cooked samples were cut into $1 \mathrm{~cm}^{3}$ thick slices and were served to panelists. Training was provided to the panelists prior to evaluation. Sensory properties of cooked samples were assessed by 29 semi-trained male and female panelist with an average age of 22 years old using a nine-point category scale (scale 1: extreme poor, scale 9: excellent) described by Sanudo et al. (1998).

\section{Statistical Analysis}

Univariate SAS (1999) program was used to control the obtained data. GLM and CORR procedures in SAS were used for analysis. When a statistical significance was detected $(\mathrm{P}<0.05)$ for sensory characteristics, paired comparisons between means were carried out using Tukey's test.

\section{Results and Discussion \\ pH and color}

The results about of $\mathrm{pH}$ and color measurements are given in Table 2. There was a significant difference between genotypes in terms of $\mathrm{pH}_{0}(\mathrm{P}<0.05)$ in the study. Genotypes showed no significance $\mathrm{pH}_{24}$ and color parameters. The highest $L$ value was observed from Eşme Kivircik lambs while the highest $a^{*}$ and $b^{*}$ values were seen in Kivircik lambs.

$\mathrm{pH}$ has a considerable influence on meat tenderness, color, taste and juiciness. After slaughtering, muscle glycogen is degraded to lactic acid and as a consequence the $\mathrm{pH}$ level of the muscle decreases. Meat quality is affected by this $\mathrm{pH}$ decline. The desirable $\mathrm{pH}$ value at $24 \mathrm{~h}$ after slaughter is between 5.50 and 5.80. It is known as the acceptable quality range. (Young and West, 2001; Öztan, 2005; Sanudo et al., 2007; Yagoubi et al., 2018). The pH values at pre-rigor mortis and $24 \mathrm{~h}$ after slaughter ranged from 6.29 to 6.44 and 5.77 to 6.02 in $M L D$ muscle respectively (Table 2). $\mathrm{pH}_{24}$ values obtained in this study were higher than previous similar researches (Sanudo et al. 1997; Diaz et al. 2003; Martinez-Cerezo et al., 2005; Ekiz et al., 2009). Results for $\mathrm{pH}_{24}$ in the present study were in agreement with Romedi and Y1lmaz (2010). Many of research were reported different $\mathrm{pH}_{24}$ value for different genotypes and breeds (Hopkins and Fogarty, 1998; Hoffman et al., 2003; Sanudo et al., 2003; Uğurlu et al., 2017). The differences between the previous literature and the present study were mainly due to non-comparative aspects such as managements and genotype differences. Considering the $\mathrm{pH}$ value obtained from the study can be said that within normal meat $\mathrm{pH}$ values. In this respect, these results indicated that the lambs did not stressed preslaughter.

Meat color varies according to myoglobin and metmyoglobin as a result of chemical reaction of myoglobin depend on oxidation and $\mathrm{pH}$ in meat. Increasing of $\mathrm{pH}$, affecting enzyme activity, leads to the darker color of the meat. The color of the meat is affected by many factors such as genetic and environment (Priola et al., 2001; Öztan, 2005). For this reason, it is difficult to make an assessment in terms of color values. Although the $L$ (brightness) and $a^{*}$ (redness) in our study were similar when compared to previous studies, $b *$ (yellowness) values were, in fact, lower than those (Diaz et al. 2003; Tejeda et al., 2008; Ekiz et al., 2009; Esenbuğa et al., 2009). Low $b^{*}$ values defined as yellowness index are expected due to low fat content of MLD muscle.

\section{Drip Loss, Cooking Loss and Shear Force}

Muscle type was a statistically significant factor for shear force, cooking loss and drip loss (Table $3, \mathrm{P}<0.01$ ). The coefficients for the regression of cold carcass weight on the same characteristics were seen to be non-significant.

The highest of the drip loss, cooking loss and shear force value were seen in $M L D(3.72 \%), M L T(22.67 \%)$ and MST $(4.38 \mathrm{~kg})$, respectively. The interaction between genotype and muscle type was statistically significant in terms of cooking loss $(\mathrm{P}<0.001)$. A comparison in terms of genotypes, cooking loss of MLT muscle in Çine Çaparı was higher than the other studied genotypes. The analysis results indicated that the highest shear force value was obtained from MST in Essme Kivircık. MLD muscle sampled from Çine Çaparı was more tender than the other studied genotypes. Phenotypic correlation coefficients between drip loss, cooking loss and shear force are given in Table 4. All coefficient of correlation were found to be positive and significant $(\mathrm{P}<0.001)$ except between drip loss and shear force. The largest correlations were between shear force and cooking loss $(\mathrm{r}=0.411$; $\mathrm{P}<0.001)$. The correlation between drip loss and cooking loss was calculated important $(\mathrm{r}=0.351 ; \mathrm{P}<0.001)$.

Table 2. The Least Squares Mean and Standard Errors of $\mathrm{pH}$ and Color Parameters

\begin{tabular}{|c|c|c|c|c|c|c|}
\hline \multirow{2}{*}{ Factors } & \multirow{2}{*}{$\mathrm{N}$} & $\mathrm{pH}_{0}$ & $\mathrm{pH}_{24}$ & $L$ & $a^{*}$ & $b^{*}$ \\
\hline & & $*$ & & & & \\
\hline $\mathrm{CC}$ & 9 & $6.44 \pm 0.051^{\mathrm{a}}$ & $6.02 \pm 0.111$ & $37.79 \pm 1.513$ & $14.49 \pm 0.844$ & $-1.12 \pm 0.504$ \\
\hline EK & 10 & $6.31 \pm 0.048^{\mathrm{a}}$ & $5.86 \pm 0.106$ & $38.42 \pm 1.435$ & $15.46 \pm 0.800$ & $-0.68 \pm 0.478$ \\
\hline $\mathrm{KR}$ & 8 & $6.46 \pm 0.054^{\mathrm{a}}$ & $5.84 \pm 0.118$ & $36.35 \pm 1.605$ & $16.55 \pm 0.895$ & $0.20 \pm 0.535$ \\
\hline KIV & 10 & $6.29 \pm 0.048^{a}$ & $5.77 \pm 0.106$ & $38.12 \pm 1.435$ & $17.06 \pm 0.800$ & $0.40 \pm 0.478$ \\
\hline General & 37 & $6.37 \pm 0.025$ & $5.87 \pm 0.055$ & $37.67 \pm 0.749$ & $15.89 \pm 0.418$ & $-0.30 \pm 0.250$ \\
\hline
\end{tabular}


Table 3. Least Squares Mean and Standard Errors for Shear Force, Cooking Loss and Drip Loss According to Muscle Types and Genotypes

\begin{tabular}{l|cccc}
\hline Factors & N & Drip Loss\% & Cooking Loss\% & Shear Force $\left(\mathrm{kg} \mathrm{cm}^{-2}\right)$ \\
\hline Muscle & & $* *$ & $* * *$ & $* *$ \\
MST & 37 & $2.35 \pm 0.273$ & $18.55 \pm 0.768$ & $4.38 \pm 0.157$ \\
MLT & 37 & $3.15 \pm 0.273$ & $22.67 \pm 0.768$ & $3.79 \pm 0.157$ \\
MLD & 37 & $3.72 \pm 0.273$ & $18.29 \pm 0.768$ & $3.71 \pm 0.157$ \\
\hline Genotype & & & & \\
CC & 27 & $3.31 \pm 0.334$ & $20.89 \pm 0.825$ & $4.05 \pm 0.186$ \\
EK & 30 & $3.20 \pm 0.307$ & $19.34 \pm 0.757$ & $4.27 \pm 0.171$ \\
KR & 24 & $3.17 \pm 0.343$ & $20.72 \pm 0.846$ & $3.80 \pm 0.191$ \\
KIV & 30 & $2.66 \pm 0.318$ & $18.68 \pm 0.784$ & $3.71 \pm 0.177$ \\
\hline Interaction (Genotype $\times$ Muscle) & & & & \\
CC $\times$ MST & 9 & $2.68 \pm 0.566$ & $18.46 \pm 1.398$ & $4.50 \pm 0.315$ \\
CC $\times$ MLT & 9 & $3.88 \pm 0.566$ & $25.86 \pm 1.398$ & $4.26 \pm 0.315$ \\
CC $\times$ MLD & 9 & $3.37 \pm 0.566$ & $18.34 \pm 1.398$ & $3.38 \pm 0.315$ \\
EK $\times$ MST & 10 & $2.50 \pm 0.531$ & $22.31 \pm 1.311$ & $4.98 \pm 0.295$ \\
EK $\times$ MLT & 10 & $3.34 \pm 0.531$ & $21.45 \pm 1.311$ & $3.72 \pm 0.295$ \\
EK $\times$ MLD & 10 & $3.75 \pm 0.531$ & $14.26 \pm 1.311$ & $4.12 \pm 0.295$ \\
KR $\times$ MST & 8 & $2.25 \pm 0.594$ & $18.41 \pm 1.466$ & $4.07 \pm 0.330$ \\
KR $\times$ MLT & 8 & $2.73 \pm 0.594$ & $22.70 \pm 1.466$ & $3.82 \pm 0.330$ \\
KR $\times$ MLD & 8 & $4.52 \pm 0.594$ & $21.05 \pm 1.466$ & $3.50 \pm 0.330$ \\
KIV $\times$ MST & 10 & $2.00 \pm 0.538$ & $14.97 \pm 1.327$ & $3.94 \pm 0.299$ \\
KIV $\times$ MLT & 10 & $2.64 \pm 0.538$ & $21.01 \pm 1.327$ & $3.42 \pm 0.299$ \\
KIV $\times$ MLD & 10 & $3.35 \pm 0.538$ & $20.06 \pm 1.327$ & $3.76 \pm 0.299$ \\
\hline Reg (Linear) Cold Carcass Weight & & $0.067 \pm 0.113$ & $-0.092 \pm 0.278$ & $-0.020 \pm 0.063$ \\
General & 111 & $3.08 \pm 0.16$ & $19.91 \pm 0.395$ & $3.96 \pm 0.089$ \\
\hline CC $=$ Cir
\end{tabular}

$\mathrm{CC}=$ Çine Çaparı, EK= Eşme Kıvırcık, $\mathrm{KR}=$ Karya, $\mathrm{KIV}=$ Kıvırcık, MST= M. semitendinosus, $M L T=M$. longissimus thoracis, MLD=M. longissimus dorsi, $* * \mathrm{P}<0.01, * * * \mathrm{P}<0.001$

Table 4. Phenotypic Correlation Coefficients between Drip Loss, Cooking Loss and Shear Force

\begin{tabular}{l|ccc}
\hline & $\mathrm{N}$ & Drip Loss & Cooking Loss \\
\hline Cooking Loss (Min-Max) & 111 & $0.351^{* * *}(0.180-0.506)$ & \\
Shear Force (Min-Max) & 111 & $0.131^{\mathrm{NS}}(-0.054-0.309)$ & $0.411^{* * *}(0.243 \pm 0.563)$ \\
\hline
\end{tabular}

$* * *=\mathrm{P}<0.001, \mathrm{NS}=$ Non-significant

Meat content constitutes a significant proportion of the water (70-80\%) as with all other foods. It is desirable to keep the water in the meat structure due to economic and technological properties. Also, removing of water from the tissue has adverse effects on sensory properties of meat such as tenderness and juiciness (Hamm, 1986; Honikel, 1988). Drip and cooking loss are affected by genotype, sex, meat chemical composition, muscle type, surface area of meat, cooking temperature and duration. The average of the cooking losses obtained in this study was $19.91 \%$. This value was lower than the reports Lanza et al. (2003), Ekiz et al. (2009) and Uğurlu et al. (2017) at the same muscle and cooking temperature. Shear force value measured in this research was lower than previous studies (Abdullah and Rasha, 2009; Çelik and Yılmaz, 2010; Uğurlu et al., 2017). Considering the results, it can be said to be considerably tender meat sampled from all studied genotyopes in terms of shear force.

\section{Fatty Acid Composition}

The results of the analysis performed according to fatty acid composition are represented Table 5. Although some fatty acids such as C10:0, C12:0, C14:0, C15:0, C16:0, tC18:1, CLA, tC18:3, C20:1, C22:0 were statistically significant in terms of genotypes. The results indicated that genotypes showed no significance effect on total fat ratio, SFA, MUFA, PUFA and P/S. The mean values for C16:0, C18:0, C18:1 and CLA, which is one of the most important in the total fatty acids, were $24.12 \%, 17.57 \%, 38.98 \%$ and
$0.40 \%$, respectively. The mean values of SFA, MUFA, PUFA and P/S ratio were $48.37 \%, 47.87 \%, 3.80 \%$ and 0.08 , respectively.

The fatty acid composition associated with meat flavor and nutritional value is an important factor in the meat quality. Although fatty acid composition obtained from studied genotypes was similar to literature, it is reasonable to mention some differences from the literature (Marmer et al., 1984; Enser et al., 2000; Wood et al., 2003; Demirel et al., 2006; Vatansever and Demirel, 2009). The differences between the previous literature and the present study were mainly due to the many factors such as breed, feeding, age that affect fatty acid composition. SFA, MUFA, PUFA and P/S ratio showed no significance in terms of genotype used in this study.

PUFA and CLA values were found to be lower than other studies (Marmer et al. 1984; Santercole et al., 2007; Vatansever and Demirel, 2009; Romedi and Y1lmaz, 2010). High oleic acid (C18:1), known mono-unsaturated fatty acid, value led to an increase MUFA value. In addition, the low PUFA caused to low P/S ratio. This situation is explained by the intensive feeding of the animal notwithstanding the pasture during the trial. Although lamb fat tissue has more than 100 varieties of fatty acids, the palmitic, stearic and oleic acids are dominant fatty acids in all (Beriain et al., 2000). The percentage of the fatty acids, obtained from the present study, was approximately $81 \%$ in the ratio of total fatty acids. 
Table 5. Least Squares Mean \pm Standard Error for Fatty Acid According to Genotypes

\begin{tabular}{|c|c|c|c|c|c|}
\hline \multirow{2}{*}{ Factors } & $\mathrm{CC}$ & EK & $\mathrm{KR}$ & KIV & General \\
\hline & $\mathrm{N}=9$ & $\mathrm{~N}=10$ & $\mathrm{~N}=8$ & $\mathrm{~N}=10$ & $\mathrm{~N}=37$ \\
\hline Fat (\%) & $8.27 \pm 1.834^{\mathrm{NS}}$ & $7.84 \pm 1.74^{\mathrm{NS}}$ & $8.29 \pm 1.945^{\mathrm{NS}}$ & $10.79 \pm 1.74^{\mathrm{NS}}$ & $8.80 \pm 0.908$ \\
\hline C10:0 & $0.15 \pm 0.008 * *$ & $0.11 \pm 0.008 * *$ & $0.15 \pm 0.009 * *$ & $0.15 \pm 0.008 * *$ & $0.14 \pm 0.004$ \\
\hline C12:0 & $0.19 \pm 0.021 * *$ & $0.14 \pm 0.02 * *$ & $0.20 \pm 0.022 * *$ & $0.25 \pm 0.02 * *$ & $0.19 \pm 0.010$ \\
\hline C14:0 & $3.01 \pm 0.176^{* * *}$ & $2.47 \pm 0.167 * * *$ & $3.06 \pm 0.187 * * *$ & $3.65 \pm 0.167 * * *$ & $3.04 \pm 0.087$ \\
\hline C15:0 & $0.71 \pm 0.056^{*}$ & $0.50 \pm 0.053 *$ & $0.57 \pm 0.059 *$ & $0.66 \pm 0.053 *$ & $0.61 \pm 0.028$ \\
\hline C16:0 & $23.63 \pm 0.687 *$ & $22.64 \pm 0.652 *$ & $24.81 \pm 0.729 *$ & $25.41 \pm 0.652 *$ & $24.12 \pm 0.34$ \\
\hline C16:1 & $2.84 \pm 0.104^{\mathrm{NS}}$ & $2.82 \pm 0.098^{\mathrm{NS}}$ & $2.69 \pm 0.11^{\mathrm{NS}}$ & $2.91 \pm 0.098^{\mathrm{NS}}$ & $2.82 \pm 0.051$ \\
\hline $\mathrm{C} 17: 0$ & $2.60 \pm 0.186^{\mathrm{NS}}$ & $2.10 \pm 0.176^{\mathrm{NS}}$ & $2.23 \pm 0.197^{\mathrm{NS}}$ & $2.33 \pm 0.176^{\mathrm{NS}}$ & $2.31 \pm 0.092$ \\
\hline $\mathrm{C} 17: 1$ & $1.50 \pm 0.115^{\mathrm{NS}}$ & $1.24 \pm 0.109^{\mathrm{NS}}$ & $1.19 \pm 0.122^{\mathrm{NS}}$ & $1.23 \pm 0.109^{\mathrm{NS}}$ & $1.29 \pm 0.057$ \\
\hline C18:0 & $16.96 \pm 1.068^{\mathrm{NS}}$ & $18.79 \pm 1.013^{\mathrm{NS}}$ & $17.6 \pm 1.132^{\mathrm{NS}}$ & $16.93 \pm 1.013^{\mathrm{NS}}$ & $17.57 \pm 0.529$ \\
\hline $\mathrm{tC} 18: 1$ & $3.92 \pm 0.429 *$ & $4.64 \pm 0.407 *$ & $3.33 \pm 0.455^{*}$ & $5.21 \pm 0.407 *$ & $4.27 \pm 0.213$ \\
\hline C18:1 & $39.81 \pm 1.303^{\mathrm{NS}}$ & $39.65 \pm 1.236^{\mathrm{NS}}$ & $40.21 \pm 1.382^{\mathrm{NS}}$ & $36.24 \pm 1.236^{\mathrm{NS}}$ & $38.98 \pm 0.645$ \\
\hline CLA & $0.42 \pm 0.031 * *$ & $0.37 \pm 0.029 * *$ & $0.33 \pm 0.033 * *$ & $0.5 \pm 0.029 * *$ & $0.40 \pm 0.015$ \\
\hline C18:2 & $2.94 \pm 0.267^{\mathrm{NS}}$ & $3.24 \pm 0.253^{\mathrm{NS}}$ & $2.57 \pm 0.283^{\mathrm{NS}}$ & $2.87 \pm 0.253^{\mathrm{NS}}$ & $2.91 \pm 0.132$ \\
\hline $\mathrm{tC} 18: 3$ & $0.06 \pm 0.004 * *$ & $0.07 \pm 0.004 * *$ & $0.05 \pm 0.004 * *$ & $0.05 \pm 0.004 * *$ & $0.06 \pm 0.002$ \\
\hline $\mathrm{C} 18: 3$ & $0.45 \pm 0.041^{\mathrm{NS}}$ & $0.35 \pm 0.039^{\mathrm{NS}}$ & $0.38 \pm 0.043^{\mathrm{NS}}$ & $0.46 \pm 0.039^{\mathrm{NS}}$ & $0.41 \pm 0.020$ \\
\hline C20:0 & $0.1 \pm 0.008^{\mathrm{NS}}$ & $0.1 \pm 0.008^{\mathrm{NS}}$ & $0.09 \pm 0.009^{\mathrm{NS}}$ & $0.1 \pm 0.008^{\mathrm{NS}}$ & $0.10 \pm 0.004$ \\
\hline C20:1 & $0.43 \pm 0.083 *$ & $0.43 \pm 0.078 *$ & $0.38 \pm 0.088 *$ & $0.71 \pm 0.078^{*}$ & $0.48 \pm 0.041$ \\
\hline $\mathrm{C} 22: 0$ & $0.1 \pm 0.024 * *$ & $0.18 \pm 0.022 * *$ & $0.07 \pm 0.025 * *$ & $0.08 \pm 0.022 * *$ & $0.11 \pm 0.012$ \\
\hline $\mathrm{C} 24: 0$ & $0.17 \pm 0.068^{\mathrm{NS}}$ & $0.19 \pm 0.065^{\mathrm{NS}}$ & $0.1 \pm 0.072^{\mathrm{NS}}$ & $0.19 \pm 0.065^{\mathrm{NS}}$ & $0.16 \pm 0.034$ \\
\hline SFA & $47.62 \pm 1.259^{\mathrm{NS}}$ & $47.15 \pm 1.195^{\mathrm{NS}}$ & $48.87 \pm 1.336^{\mathrm{NS}}$ & $49.83 \pm 1.195^{\mathrm{NS}}$ & $48.37 \pm 0.624$ \\
\hline MUFA & $48.50 \pm 1.212^{\mathrm{NS}}$ & $48.87 \pm 1.15^{\mathrm{NS}}$ & $47.8 \pm 1.286^{\mathrm{NS}}$ & $46.29 \pm 1.15^{\mathrm{NS}}$ & $47.87 \pm 0.601$ \\
\hline PUFA & $3.88 \pm 0.313^{\mathrm{NS}}$ & $4.12 \pm 0.297^{\mathrm{NS}}$ & $3.33 \pm 0.332^{\mathrm{NS}}$ & $3.88 \pm 0.297^{\mathrm{NS}}$ & $3.80 \pm 0.155$ \\
\hline $\mathrm{P} / \mathrm{S}$ & $0.08 \pm 0.007^{\mathrm{NS}}$ & $0.09 \pm 0.007^{\mathrm{NS}}$ & $0.07 \pm 0.007^{\mathrm{NS}}$ & $0.08 \pm 0.007^{\mathrm{NS}}$ & $0.08 \pm 0.003$ \\
\hline
\end{tabular}

$\mathrm{CC}=$ Çine Çaparı, EK= Eşme Kıvırcık, KR= Karya, KIV $=$ Kıvırcık, ${ }^{*} \mathrm{P}<0.05, * * \mathrm{P}<0.01, * * * \mathrm{P}<0.001$

Table 6. Basic Statistics of the Sensory Characteristics in MLD Muscle According to Genotypes

\begin{tabular}{|c|c|c|c|c|}
\hline Variable & Genotype & $\mathrm{N}$ & $\overline{\bar{X}} \pm \mathrm{SE}$ & $\mathrm{CV}(\%)$ \\
\hline \multirow{4}{*}{ Odor } & EK & 29 & $4.79 \pm 0.352$ & 39.58 \\
\hline & $\mathrm{CC}$ & 29 & $4.17 \pm 0.268$ & 34.54 \\
\hline & KR & 29 & $5.59 \pm 0.300$ & 28.91 \\
\hline & KIV & 29 & $5.45 \pm 0.342$ & 33.84 \\
\hline \multirow{4}{*}{ Tenderness } & EK & 29 & $6.10 \pm 0.307$ & 27.12 \\
\hline & $\mathrm{CC}$ & 29 & $5.79 \pm 0.327$ & 30.39 \\
\hline & $\mathrm{KR}$ & 29 & $6.41 \pm 0.308$ & 25.86 \\
\hline & KIV & 29 & $6.28 \pm 0.354$ & 30.38 \\
\hline \multirow{4}{*}{ Juiciness } & EK & 29 & $5.17 \pm 0.340$ & 35.45 \\
\hline & $\mathrm{CC}$ & 29 & $5.38 \pm 0.278$ & 27.85 \\
\hline & KR & 29 & $5.17 \pm 0.314$ & 32.71 \\
\hline & KIV & 29 & $5.69 \pm 0.341$ & 32.24 \\
\hline \multirow{4}{*}{ Flavour } & EK & 29 & $5.24 \pm 0.296$ & 30.45 \\
\hline & $\mathrm{CC}$ & 29 & $5.07 \pm 0.276$ & 29.32 \\
\hline & KR & 29 & $6.03 \pm 0.274$ & 24.45 \\
\hline & KIV & 29 & $6.07 \pm 0.289$ & 25.65 \\
\hline \multirow{4}{*}{ Overall Acceptability } & EK & 29 & $5.14 \pm 0.292$ & 30.65 \\
\hline & $\mathrm{CC}$ & 29 & $4.93 \pm 0.248$ & 27.06 \\
\hline & KR & 29 & $6.07 \pm 0.243$ & 21.54 \\
\hline & KIV & 29 & $5.97 \pm 0.395$ & 35.70 \\
\hline
\end{tabular}

$\overline{\mathrm{CC}}=$ Çine Çaparı, EK= Eşme Kıvırcık, KR= Karya, KIV =Kıvırcık

Palmitic acid, stearic acid, and oleic acid and $\mathrm{P} / \mathrm{S}$ ratio results in this study were in agreement when compared to Kivircik and Sakız lambs (Demirel et al., 2006; Vacca et al., 2008; Romedi and Y1lmaz, 2010). Additionally, stearic acid and oleic acid were significantly higher than reported values by Vacca et al. (2008). Although the MUFA values in our study were higher, PUFA and P/S ratio were, in fact, lower than values reported by Vatansever and Demirel (2009). Mean CLA, SFA, MUFA and PUFA values were lower than noticed by Diaz et al. (2005).

\section{Sensory Evaluation}

Aritmetic means of the sensory properties (odor, tenderness, juiciness, flavor, and acceptability) given for the $M L D$ muscle are summarized in Table 6. The least squares mean and standard error for sensory characteristics according to genotypes are given in Table 7. High coefficient of variation was seen in all genotypes for all studied parameters. Although, the highest score for odor (5.59) and tenderness (6.41) was observed in Karya lambs, the highest juiciness (5.69) and flavor (6.07) scores were 
observed in Kivircik lamb. There was a significant difference between genotypes for odor $(\mathrm{P}<0.01)$, flavor $(\mathrm{P}<0.05)$ and overall acceptability $(\mathrm{P}<0.05)$ in the present study. The results showed that the highest tenderness value obtained from Kivircik lamb was found to be parallel to the assessment of sensory characteristics.

Therefore, many different methods have been developed for sensory evaluation; scoring system is usually used in meat and meat products. Eating quality and flavour are associated with many chemical and physical properties of the meat. For example, juiciness and tenderness depend not only on the fat content, but also on the ability to water holding capacity. Tenderness, juiciness and flavour are complex features and they are influenced by many factors in the production and processing processes. There are also well-trained panelists are needed to evaluate these characteristics in sensory tests (Warriss, 2000).
Many factors such as attention, detection capability, prejudice and trend, habits, age and sex of panelists effect on sensory tests (Sanudo et al., 1998; Öztan, 2005). Sensory analysis is reported to be highly subjective (Risvik, 1994). High variation in all sensory parameters was determined in the present study. This result was expected considering these measurements is biased. The higher scores are given to Kivircik meat samples by the panelist in terms of juiciness and flavour, although there were no significant differences between other genotypes. The studied genotypes showed that they have a significant potential for high-quality lamb meat production in Turkey. In addition, taking into account that, according to (Safari et al., 2001), tenderness, flavour and juiciness are the most important sensory properties in overall acceptability, the $M L D$ muscle of Karya lambs was more acceptable than the others.

Table 7. Least Squares Mean \pm Standard Error for Sensory Characteristics According to Genotype

\begin{tabular}{c|cccccc}
\hline \multirow{2}{*}{ Factor } & \multirow{2}{*}{$\mathrm{N}$} & Odor & Tenderness & Juiciness & Flavor & $\begin{array}{c}\text { Overall } \\
\text { Acceptability }\end{array}$ \\
\cline { 3 - 6 } Genotype & & $* *$ & & & $*$ & $*$ \\
EK & 29 & $4.79 \pm 0.317^{\mathrm{ab}}$ & $6.10 \pm 0.325$ & $5.17 \pm 0.319$ & $5.24 \pm 0.284^{\mathrm{a}}$ & $5.14 \pm 0.301^{\mathrm{ab}}$ \\
CC & 29 & $4.17 \pm 0.317^{\mathrm{c}}$ & $5.79 \pm 0.325$ & $5.38 \pm 0.319$ & $5.07 \pm 0.284^{\mathrm{a}}$ & $4.93 \pm 0.301^{\mathrm{c}}$ \\
KR & 29 & $5.59 \pm 0.317^{\mathrm{a}}$ & $6.41 \pm 0.325$ & $5.17 \pm 0.319$ & $6.03 \pm 0.284^{\mathrm{a}}$ & $6.07 \pm 0.301^{\mathrm{a}}$ \\
KIV & 29 & $5.45 \pm 0.317^{\mathrm{a}}$ & $6.28 \pm 0.325$ & $5.69 \pm 0.319$ & $6.07 \pm 0.284^{\mathrm{a}}$ & $5.97 \pm 0.301^{\mathrm{ab}}$ \\
General & 116 & $5.00 \pm 0.159$ & $6.15 \pm 0.162$ & $5.35 \pm 0.160$ & $5.60 \pm 0.142$ & $5.53 \pm 0.150$ \\
\hline
\end{tabular}

$\mathrm{CC}=$ Çine Çaparı, $\mathrm{EK}=$ Eşme Kıvırcık, $\mathrm{KR}=$ Karya, $\mathrm{KIV}=$ Kıvırcık, ${ }^{\mathrm{a}, \mathrm{b}, \mathrm{c}}$ In the same column, means with different letters differ significantly. ${ }^{*} \mathrm{P}<0.05$, $* * \mathrm{P}<0.01$

The score of odor, tenderness, flavor and overall acceptability was found to be lowest in Çine Çaparı lambs. Sanudo et al. (1997) reported that the breed has a significant effect on meat color, cooking loss, tenderness and juiciness of meat for the Churra, Castellana, Spanish Manchega and Awassi crossbred lambs. Therefore, there were non-significant differences between genotypes for tenderness and juiciness in this study. This result was in agreement previous study except tenderness in Merino, Ramlıç Kıvırcık, Sakız and İmroz breeds (Ekiz et al., 2009) researches.

\section{References}

Abdullah A, Rasha Q. 2009. Effect of slaughter weight and aging time on the quality of meat from Awassi ram lambs. Meat Science, 82(3): 309-316.

Beriain MJ, Purroy A, Treacher T, Bas P. 2000. Effect of animal and nutritional factors and nutrition on lamb meat quality. In: Ledin I. (ed.), Morand-Fehr P. (ed.). Sheep and goat nutrition: Intake, digestion, quality of products and rangelands. Zaragoza, CIHEAM, p. 75-86 (Cahiers Options Méditerranéennes; n. 52).

Ceyhan A, Erdoğan İ, Sezenler T. 2007. Gen kaynağı olarak korunan Kıvırcık, Gökçeada ve Sakız koyun ırklarının bazı verim özellileri. Tekirdağ Ziraat Fakültesi Dergisi, 4(2): 211218.

Celik R, Y1lmaz A. 2010. Certain meat quality characteristics of Awassi and Turkish Merino $\times$ Awassi (F1) lambs. Turkish Journal of Veterinary and Animal Science, 34(4): 349-357.

Demirel G, Özpınar H, Nazlı B, Keser O. 2006. Fatty acids of lamb meat from two breeds fed different forage: concentrate ratio. Meat Science, 72: 229-235.
Diaz MT, Velasco S, Perez C, Lauzurica S, Huidobro F, Caneque V. 2003. Physicochemical characteristics of carcass and meat Manchego-breed suckling lambs slaughter at different weights. Meat Science, 65: 1085-1093.

Diaz MT, Ivarez IA, De la Fuente J, Sanudo C, Campo MM, Oliver MA, Furnols MF, Montossi F, San Julia'nR, Nute GR, Caneque V. 2005. Fatty acid composition of meat from typical lamb production systems of Spain, United Kingdom, Germany and Uruguay. Meat Science, 71: 256-263.

Ekiz B, Yılmaz A, Özcan M, Kaptan C, Hanoğlu H, Erdoğan I, Yalçıntan H. 2009. Carcass measurements and meat quality of Turkish Merino, Ramlic, Kivircik, Chios and Imroz lambs raised under an intensive production system. Meat Science, 82: 64-70.

Enser M, Richardson RI, Wood JD, Gill BP, Sheard PR. 2000. Feeding linseed to increase the n-3 PUFA of pork: fatty acid composition of muscle, adipose tissue, liver and sausages. Meat Science, 55: 201-212.

Esenbuğa N, Macit M, Karaoğlu M, Aksakal V, Aksu MI, Yörük MA, Gül M. 2009. Effect of breed on fattening performance, slaughter and meat quality characteristics of Awassi end Morkaraman lambs. Livestock Science, 123: 255-260.

Gardener GE, Kennedy L, Milton JTB, Pethick DW. 1999. Glycogen metabolism and ultimate $\mathrm{pH}$ of muscle in merino, first-cross, and second-cross whether lambs as affected by stress before slaughter. Australian Journal of Agricultural Research, 50: 175-181.

Hamm R. 1986. Functional properties of the myofibrillar system and their measurements. In PJ. Bechtel, (editor). Muscle as food. p. 135-199. New York Academic Press, Inc.

Hoffman LC, Muller M, Cloete SWP, Schmidt D. 2003. Comparison of six crossbred lamb types: Sensory, physical and nutritional meat quality characteristics. Meat Science, 65: $1265-1274$ 
Honikel KO. 1988. How to measure the water holding capacity of meat? Meat Science, 49: 447-457.

Hopkins DL, Fogarty NM. 1998. Diverse lamb genotypes 2.Meat $\mathrm{pH}$, colour and tenderness. Meat Science, 49: 477488.

Kandemir Ç, Adanacıoğlu H, Taşkın T, Koşum N. 2019. Türkiye'de Koyun ve Koyun Eti Fiyatlarının Bölgelere Göre Çok Boyutlu Ölçekleme Analizi ile Karşılaştırılması. Tekirdağ Ziraat Fakültesi Dergisi, 16 (3): 315-327.

Lanza M, Bella M, Priolo A, Fasone V. 2003. Peas (Pisum sativum L.) as an alternative protein source in lamb diets: Growth performances, and carcass and meat quality. Small Ruminant Research, 47: 63-68.

Marmer WN, Maxwell RJ, Williams JE. 1984. Effects of dietary regimen and tissue site on bovine fatty acid profiles. Journal of Animal Science, 59: 109-121

Martinez-Cerezo S, Sanodu C, Panea B, Medel I, Delfa R, Sierra I, Beltran JA, Cepero C, Olleta JL. 2005. Breed, slaughter weight and ageing time effects on physico-chemical characteristics of lamb meat. Meat Science, 69: 325-333

Öztan A. 2005. Meat Science and Technology (Et Bilimi ve Teknolojisi). Vol. 1. Ankara. TMMOB Gıda Mühendisleri Odası Yayınları.

Priola A, Micol D, Agabriel J. 2001. Effects of grass feeding systems on ruminant meat color and flavour. A review. Animal Research, 50: 185-200.

Risvik E. 1994. Sensory properties and preferences. Meat Science, 36: 67-77.

Romedi Ç, Y1lmaz A. 2010. Certain meat characteristics of Awassi and Turkish Merino x Awassi $\left(\mathrm{F}_{1}\right)$ lambs. Turk. J. Vet. Anim. Sci., 34 (4): 249-257.

Safari E, Fogarty NM, Ferrier GR, Hopkins LD, Gilmour A. 2001. Diverse lamb genotypes. 3. Eating quality and the relationship between its objective measurement and sensory assessment. Meat Science, 57: 153-159.

Sanudo C, Campo MM, Sierra I, Maria GA, Oletta JL, Santolaria P. 1997. Breed effect on carcass and meat quality of suckling lamb. 1997. Meat Science, 46 (4): 357-365.

Sanudo C, Sánchez A, Alfonso M. 1998. Small ruminants production systems and factors affecting lamb meat quality. Meat Science, 49 (1): 29-64.

Sanudo C, Alfonso M, Sanchez A, Berge P, Dransfield E, Zygoiannis D. 2003. Meat texture of lambs from different European production systems. Aust. J. Agric. Res., 54: 551560.
Sanudo C, Campo M, Olleta JL, Joy M, Delfa R. 2007. Valuation of carcass and meat quality in cattle and sheep. Methodologies to evaluate meat quality in small ruminants. Wageningen Academic Publishers, EAAP. No: 123, The Netherlands, 225.

Santercole V, Mazzete R, De Santis EPL, Banni S, Goonewadene L, Kramer JKG. 2007. Total lipids of Sarda sheep meat that include the fatty acid and alkenyl composition and the cla and trans-18:1 isomers. Lipid, 42: 361-382.

SAS. 1999. The SAS system Version 8. In: SAS institute Inc., Cary, NC, USA.

Tejeda JF, Pena RE, Andres AI. 2008. Effect of live weight and sex on pyhsico-chemical and sensorial characterictics of Merino lamb meat. Meat Science, 80: 1061-1067.

Tokuşoğlu Ö. 2005. Chemical and Microbiological Quality Control in Meat and Meat Products (Et ve Et Ürünlerinde Kimyasal ve Mikrobiyolojik Kalite Kontrol). Celal Bayar Üniversitesi. Manisa.

Uğurlu M, Ekiz B, Teke B, Salman M, Akdağ F, Kaya İ. 2017. Meat quality traits of male Herik lambs raised under an intensive fattening system. Turkish Journal of Veterinary and Animal Sciences, 41: 425-430.

Ünal N, Akçapınar H. 1996. Sheep Breeding Studies in the World and Turkey (Dünyada ve Türkiye'de Koyun Islah Çalışmaları). Türk Veteriner Hekimleri Dergisi, 8 (2): 18-26.

Vacca GM, Carcangiu V, Pazzola M, Mura MC, Luridiana S, Tilloca G. 2008. Productive performance and meat quality of MouflonxSarda and SardaxSarda suckling lamb. Meat Science, 80: 326-334.

Vatansever L, Demirel G. 2009. Fatty acid content and composition of Turkish beef and lamb at retail. Turkish Journal of Veterinary and Animal Sciences, 33 (1): 71-75.

Wood JD, Richardson RI, Nute GR, Fisher AV, Campo MM, Kasapidou E, Sheard PR, Enser M. 2003. Effects of fatty acids on meat quality: a review. Meat Science, 66: 21-32.

Yagoubi Y, Hajji H, Smeti S, Mahouachi M, Kamoun M. 2018. Growth performance, carcass and noncarcass traits and meat quality of Barbarine lambs fed rosemary distillation residues. Animal, 12: 1-8.

Young OA, West J. 2001. Meat Color. In. Meat science and applications. New York. Marcel Dekker.

Warriss PD. 2000. Meat Science, An Introductory Text. Wallingford: CABI Publishing. doi:10.4102/jsava.v71i4.731. 